\title{
Effect of Different Sewing Parameters on Lockstitch Seam Strength for Denim Fabric
}

\author{
Alimran Hossain 1,*, Md. Rokonuzzaman ${ }^{1}$, Md. Abu Bakar Siddiquee ${ }^{1}$, Md. Abdullah Al Mamun ${ }^{1}$, S. M. \\ Farhana Iqbal ${ }^{2}$ and Md. Azharul Islam ${ }^{1}$
}

\author{
${ }^{1}$ Department of Textile Engineering, Mawlana Bhashani Science and Technology University, Tangail-1902, Bangladesh \\ ${ }^{2}$ Department of Yarn Engineering, Bangladesh University of Textiles, Dhaka-1208, Bangladesh
}

Received: November 30, 2020, Revised: December 17, 2020, Accepted: December 18, 2020, Available Online: December 19, 2020

\begin{abstract}
Seam strength plays a very important role in acquiring the desired quality seam which ultimately defines the quality of any clothing. The paper is aimed to study the strength of seam produced from denim fabric, how different sewing parameters like sewing thread type, type of seam, seam direction as well as the density of stitches influence the strength of seam, and it is observed that they have direct effect on lockstitch seam strength of denim fabric with various degree. For research denim fabric with $3 / 1$ weaves structure and three different sewing threads namely $100 \%$ cotton spun with 14 tex linear density, $100 \%$ polyester spun with 24 tex and 60tex linear density were used. Seam class used for the research was superimposed seam prepared with two layers, SSa and three layers, SSb. The samples were made by stitching with lockstitch sewing machine both in warp and weft way. Three different stitch densities were used to sew the samples and they were-7, 9 and 11 stitches per inch. The strength of the produced seams was tested on a universal strength tester machine-the titan tensile strength tester. Test was performed according to ASTM D5034 test method. The outcome of the research shows that seam type, seam direction, thread types, and stitch density have direct effect on lockstitch seam strength of denim fabric with various degrees. Higher seam strength was obtained for the SSb type seam produced in warp direction with coarser sewing thread (60tex) and 11 stitches per inch (SPI). The influence of independent variables on the seam strength was assessed statistically using a multivariate variance analysis (ANOVA) with the help of SPSS software and it was found that they effect significantly. Regression analysis was done to develop the regression equation to predict lockstitch seam strength before production process.
\end{abstract}

Keywords: Denim Fabric, Seam Strength, Stitch Density, Seam Type, Stitch per Inch.

This work is licensed under a Creative Commons Attribution-Non Commercial 4.0 International

\section{Introduction}

Apparel manufacturing technology depends on the conversion of the fabric from two dimensional (2D) into three dimensional (3D) structures to fit human body [1]. Though there is a considerable improvement of techniques and technologies has been emerged in the apparel manufacturing, still the dominating group of methods for joining the garment elements is the sewn seams made by sewing threads [2].

The clothing industries are mainly concerned about the secondary characteristics of fabric that is the reactions of the fabric to an applied dynamic force and focus on the quality of seam at the time of fabrication and production of clothing [3],[4]. So good seams are important factors to determine clothing quality which is a big deal in today's competitive world market as quality can be seen as the synonym of excellence [5] and as a means to make differentiation of different products having perceived value [6].

On the other hand, quality of a seam can be viewed from its performance and appearance [7]. Seam performance that is, appearance, seam strength, elastic property, and durability depend on the seam type and stitch density of the seam, tension of the sewing thread and the seam efficiency of the fabric.

Seam durability can be measured through seam efficiency where seam strength is the driving factor [8]. As the standard of any garments is dependent on the quality of seam, the applied seams to make the garments have to fulfill the above mentioned criteria, among which seam strength and appearance of the seams have big importance [9], [10].
Another important matter is that the seam should have such stretchability so that the users can have free movement without breaking the seams.

In general, seam efficiency ranges between $85 \%$ and $90 \%$ but it can be optimized by optimizing seam strength considering different sewing parameters like type of seam, stitch types, stitch density, and type of sewing threads and selection of needle [12].

Rengasamy et al. [13] and Nayak et al. [14] showed the influence of types of sewing thread on the seam efficiency. Impact of linear density of sewing thread has been studied by different researchers [10],[15],[16] and it has been found that the linear density of sewing thread is one of the most influencing factors for the seam strength. Barbulov et al. [11] studied the impact of stitch density and of the type of sewing thread on seam strength. Akter and Khan (2015) [17] studied the influence of stitch type and sewing thread on seam strength and efficiency of the superimposed seam for cotton apparel. The effect of the different number of sewn layers was first studied by [1] Frydrych et al. (2016) along with other sewing parameters. Yassen (2017) [18] showed the effects of sewing thread count, sewing needle size, stitch density along with fabric characteristics on seam strength, and found that seam strength is significantly influenced by both sewing and fabric characteristics.

This research work is an attempt to investigate and show how different sewing parameters for example sewing thread, seam type, stitch density, sewn fabric layers affect seam quality in terms of seam strength as well as to develop a regression equation to predict the lockstitch seam strength for denim fabrics. 


\section{Experimental Details}

Denim fabric of $98 \%$ cotton and $2 \%$ spandex yarn, $3 / 1$ twill was taken with the specifications given in Table 1. Sewing parameters and sewing threads properties were given in Table 2 and Table 3. A simplified flow chart of research methodology is given in Fig. 1.

Table 1 Fabric characteristics

\begin{tabular}{|c|c|c|c|c|c|}
\hline Parameters & Unit & Value & Parameters & Unit & Value \\
\hline Thickness & $\mathrm{mm}$ & 0.52 & $\begin{array}{l}\text { Warp yarn } \\
\text { count }\end{array}$ & tex & 80 \\
\hline $\begin{array}{l}\text { Surface } \\
\text { density }\end{array}$ & $\mathrm{g} / \mathrm{m}^{2}$ & 182 & $\begin{array}{l}\text { Weft yarn } \\
\text { count }\end{array}$ & tex & 70 \\
\hline $\begin{array}{l}\text { Warp breaking } \\
\text { force }\end{array}$ & $\mathrm{cN}$ & 1025 & $\begin{array}{c}\text { Warp yarn } \\
\text { elongation at } \\
\text { break }\end{array}$ & $\%$ & 11 \\
\hline $\begin{array}{l}\text { Weft breaking } \\
\text { force }\end{array}$ & $\mathrm{cN}$ & 890 & $\begin{array}{c}\text { Weft yarn } \\
\text { elongation at } \\
\text { break }\end{array}$ & $\%$ & 8 \\
\hline $\begin{array}{l}\text { Warp density } \\
\qquad(\mathrm{EPcm})\end{array}$ & $\mathrm{cm}^{-1}$ & 28 & $\begin{array}{l}\text { Warp yarn } \\
\text { tenacity }\end{array}$ & cN/tex & 12.81 \\
\hline $\begin{array}{l}\text { Weft density } \\
\text { (PPcm) }\end{array}$ & $\mathrm{cm}^{-1}$ & 20 & $\begin{array}{l}\text { Weft yarn } \\
\text { tenacity }\end{array}$ & cN/tex & 12 \\
\hline
\end{tabular}

Table 2 Selection of different sewing parameters

\begin{tabular}{|c|c|c|}
\hline $\begin{array}{c}\text { Sewing } \\
\text { parameters }\end{array}$ & $\begin{array}{c}\text { Expression/ } \\
\text { Value }\end{array}$ & Elaboration \\
\hline Seam class & SS & Superimposed seam * \\
\hline Seam type & $\mathrm{SSb}$ & $\begin{array}{l}\text { Superimposed seam with two } \\
\text { layers* } \\
\text { Superimposed seam with three } \\
\text { layers* }\end{array}$ \\
\hline $\begin{array}{l}\text { Seam } \\
\text { direction }\end{array}$ & $\begin{array}{l}\text { Warp, } \\
\text { Weft }\end{array}$ & $\begin{array}{l}\text { Seams were prepared in warp } \\
\text { and weft direction }\end{array}$ \\
\hline $\begin{array}{l}\text { Stitch density } \\
\text { (SPI) }\end{array}$ & $7,9,11$ & $\begin{array}{l}\text { They are expressed as SD1, } \\
\text { SD2 and SD } 3 \text { respectively }\end{array}$ \\
\hline $\begin{array}{l}\text { Sewing } \\
\text { thread }\end{array}$ & $\begin{array}{l}\text { ST1, ST2, } \\
\text { ST3 }\end{array}$ & $\begin{array}{l}\text { Represent sewing thread one, } \\
\text { two and three respectively }\end{array}$ \\
\hline $\begin{array}{l}\text { Needle size } \\
\text { (Metric) }\end{array}$ & $\begin{array}{l}100,100, \\
150\end{array}$ & $\begin{array}{l}\text { Corresponding sewing threads } \\
\text { are ST1, ST2 and ST3 } \\
\text { respectively }\end{array}$ \\
\hline
\end{tabular}

(* According to ASTM D 6193)

Table 3 Sewing threads properties

\begin{tabular}{ccccc}
\hline Parameters & Unit & ST1 & ST2 & ST3 \\
\hline Ply number & - & 2 & 2 & 3 \\
Composition & - & $\begin{array}{c}100 \% \\
\text { polyester } \\
\text { Spun }\end{array}$ & $\begin{array}{c}\text { Cotton } \\
\text { Spun }\end{array}$ & $\begin{array}{c}100 \% \\
\text { polyester } \\
\text { Spun }\end{array}$ \\
$\begin{array}{c}\text { Linear } \\
\text { density }\end{array}$ & tex & 14 & 24 & 60 \\
$\begin{array}{c}\text { Ticket } \\
\text { number }\end{array}$ & & 215 & 125 & 50 \\
$\begin{array}{c}\text { Breaking } \\
\text { force }\end{array}$ & $\mathrm{N}$ & 8.4 & 10.6 & 24 \\
$\begin{array}{c}\text { Elongation } \\
\text { at break }\end{array}$ & $\%$ & 17.87 & 7.37 & 46
\end{tabular}

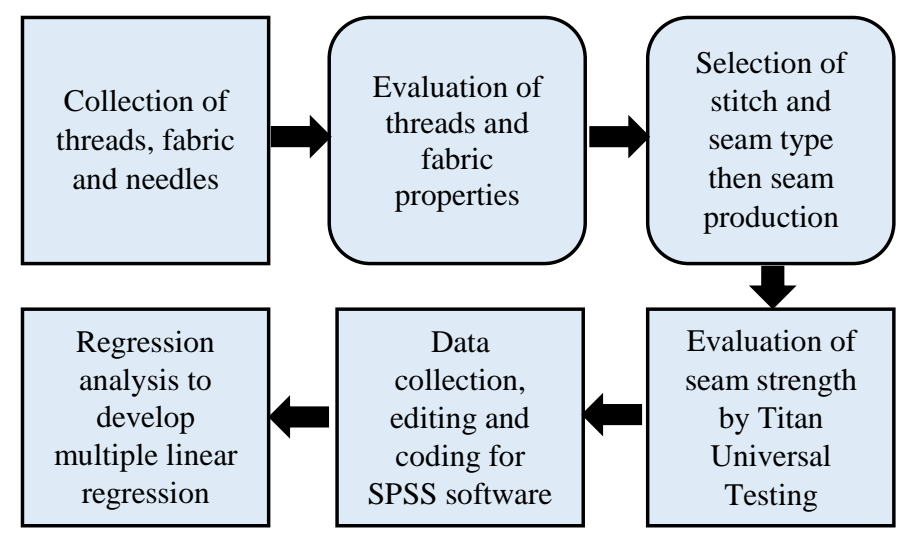

Fig. 1 Simplified research methodology

\subsection{Sample Preparation}

A superimposed seam class of SSa and SSb type with 25.4 mm seam allowance and according to ASTM D 6193, lockstitch class 301 were used for sewing the samples. Selection of needle size to sew the samples has been shown in the Table 2. Samples were stitched along the seam line both in warp and weft way of the fabric. The fabric was sewn with three different stitch densities to see the effect of stitch density on seam strength.

\subsection{Seam strength evaluation}

Grab test (ASTM D5034) as a test method was used to determine the seam strength. Samples with $350 \mathrm{~mm}$ length among which $150 \mathrm{~mm}$ in one side of the seam line and $200 \mathrm{~mm}$ on another side of the seam along with $100 \mathrm{~mm}$ in width which is parallel to the seam line were made as shown in Fig. 2. During the test, samples were subjected to $1 \%$ tension of the approximate breaking load. The value presented here is the average of five specimen tested consecutively.

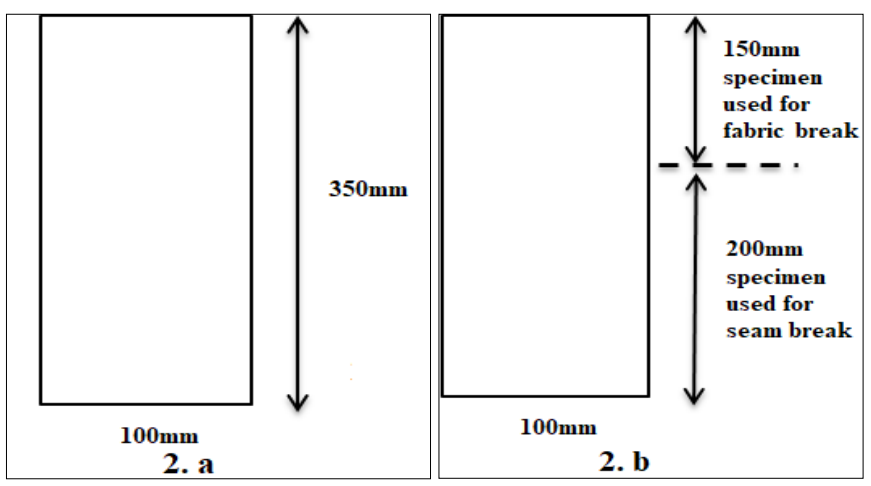

Fig. 2 Dimension of cut specimen from fabric (2.a) and Seamed specimen (2.b)

\section{Results and Discussion}

\subsection{Effect of Seam Type on Seam Strength}

Two different types of superimposed seams were made and they were SSa and SSb type seam that is they were different by their layers. Seam SSa has two layers of fabric whereas seam SSb has three layers of fabric. The graphical representation presented in Fig. 4(c) shows that there is noticeable difference in seam strength with the increase of layers of fabric in the seam and this can also be understood from the variance analysis presented in Table 4. It is also found that seam strength gets increased as the increase of fabric layers for all kind of sewing parameters that is seam direction, sewing thread and stitch density [see Fig. 3]. 
The fact is that, an increase in fabric layer increases contact points number between fabric yarns and sewing threads, as a result a tighter surface is obtained. Thus, the distribution of tensile forces will take place over a larger number of points and the resistance will be higher.

\subsection{Effect of Seam Direction on Seam Strength}

Though warp seam strength was higher than that of weft in most of the cases, in some cases, warp and weft seam strength were found equal [see Fig. 3]. From the Fig. 4(d), it is obvious that direction of seam has significant effect on strength of the seam of the sewn fabrics. The fact can be supposed that the lower seam strength of the fabric can result from the lesser number of intersection points between sewing thread and yarns of the fabric.

\subsection{Effect of Sewing Thread on Seam Strength}

It is an established truth that the higher the strength of sewing threads the higher the seam strength of the sewn fabrics. This is because, the strength of the sewing threads adds the strength to the seam sewn by the threads. This study also reveals the same result and supports the results of many other researchers
[19],[20]. From the correlation analysis it is found that there is very strong correlation between sewing thread linear density and seam strength [see Table 4]. The effect of sewing threads on seam strength has been presented graphically in Fig. 4. a. The effect of sewing threads varying other sewing parameters has been represented in the Fig. 3 and it is found that seam strength always gets increased as the increase of sewing thread size for all kind of sewing parameters that is seam direction, fabric layers and stitch density. The fact is that the coarser sewing thread contains more number of fibres resulting in high seam strength.

\subsection{Effect of Stitch Density on Seam Strength}

The effect of stitch density on the strength of the lockstitch seam is found very prominent (see Fig. 4(b)) and it is found as the second most influential factor of seam strength; statistical analysis also reports the same issue (see Table 4). It has also been found that with the increase of stitch density the seam strength also increases and the effect is obvious for all kind of other sewing parameters like seam type, seam direction, sewing thread types (see Fig. 3). In fact, with the increase of stitch density the number of loops per unit length of the fabric increases; therefore, the higher force is required to deform such a seam.

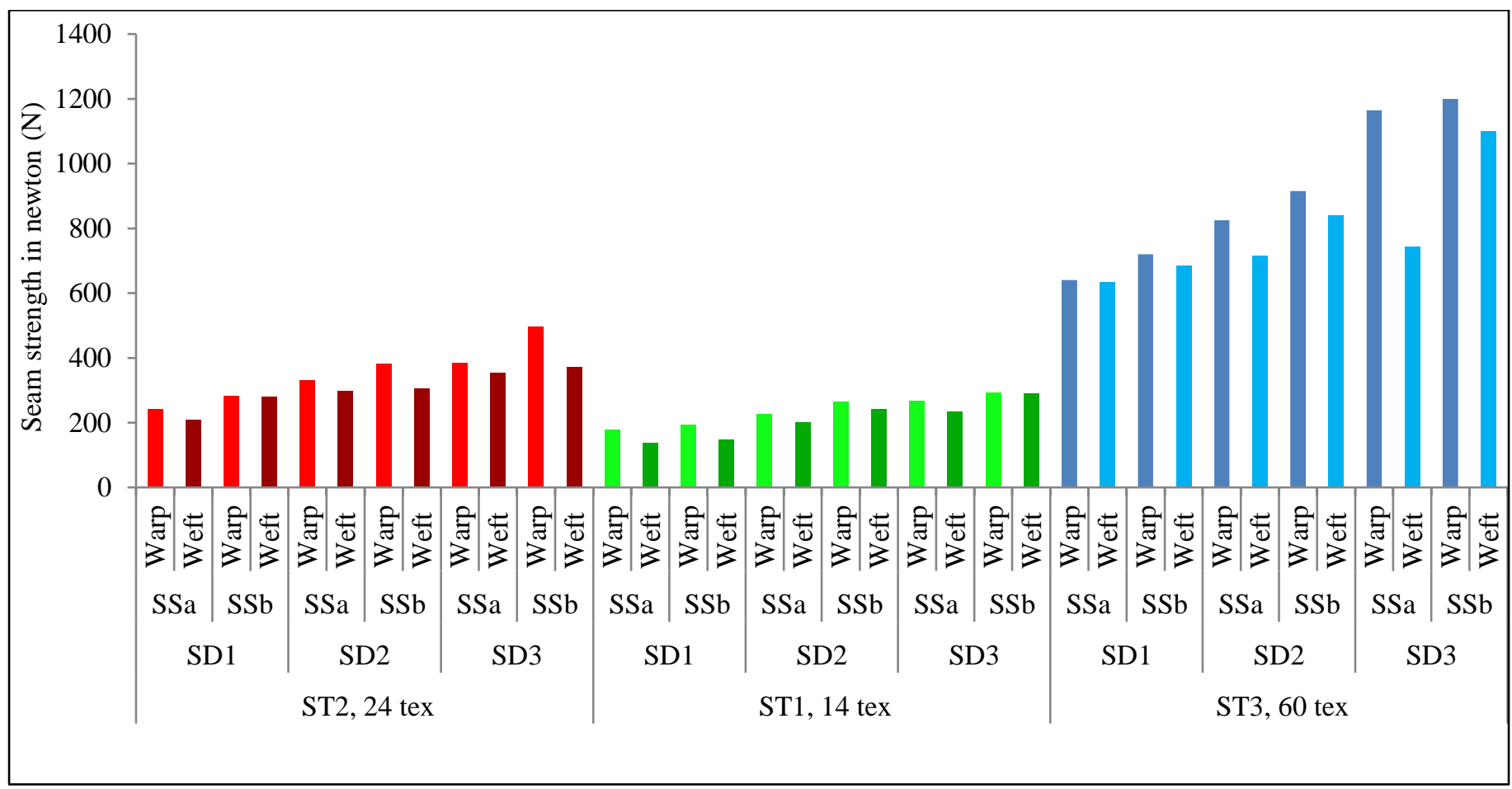

Fig. 3 Effect of seam type, seam direction, sewing thread, and stitch density on seam strength

Table 4 Correlation analysis of different parameters

Correlations

\begin{tabular}{cccccc}
\hline Variables & Seam strength & Sewing Thread & Stitch Density & Seam type & Seam direction \\
\hline Seam strength & 1 & $0.851^{* *}$ & 0.289 & 0.113 & -0.113 \\
Sewing Thread & $0.851^{* *}$ & 1 & 0 & 0 & 0 \\
Stitch Density & 0.289 & 0 & 0 & 0 & 1 \\
Seam type & 0.113 & 0 & 0 & 0 & 0 \\
Seam direction & -0.113 & 0 & & 0 \\
\hline
\end{tabular}




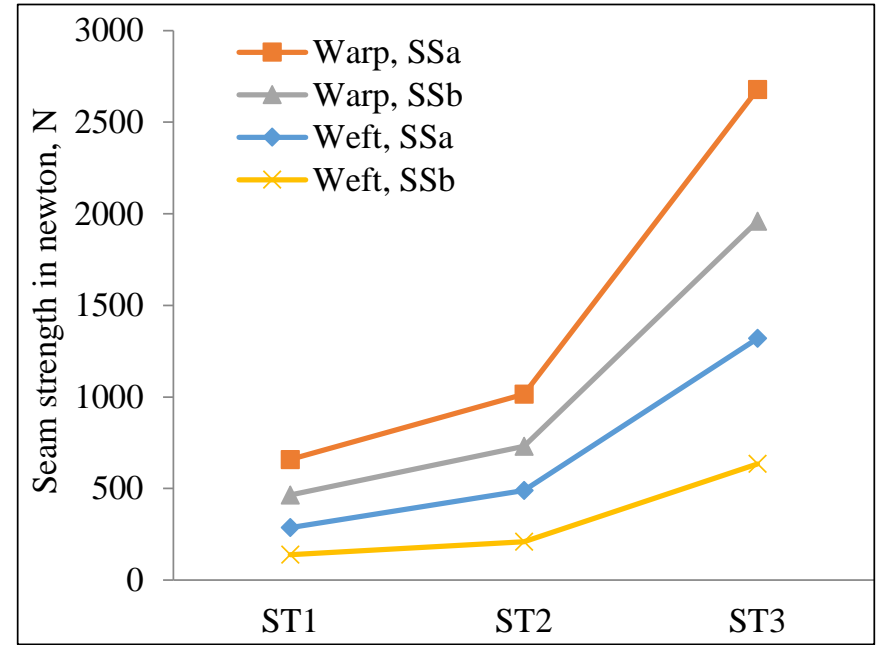

(a)

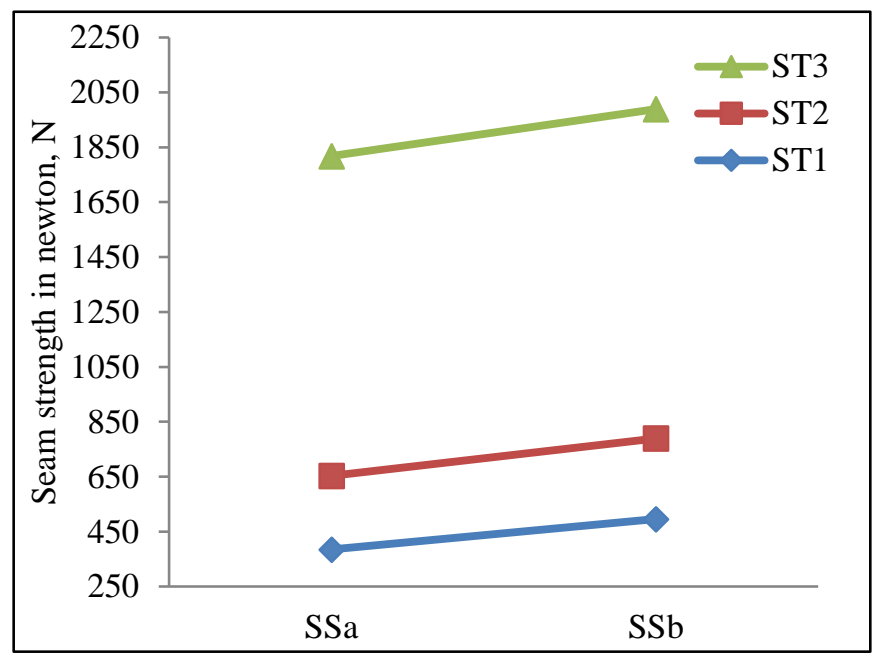

(c)

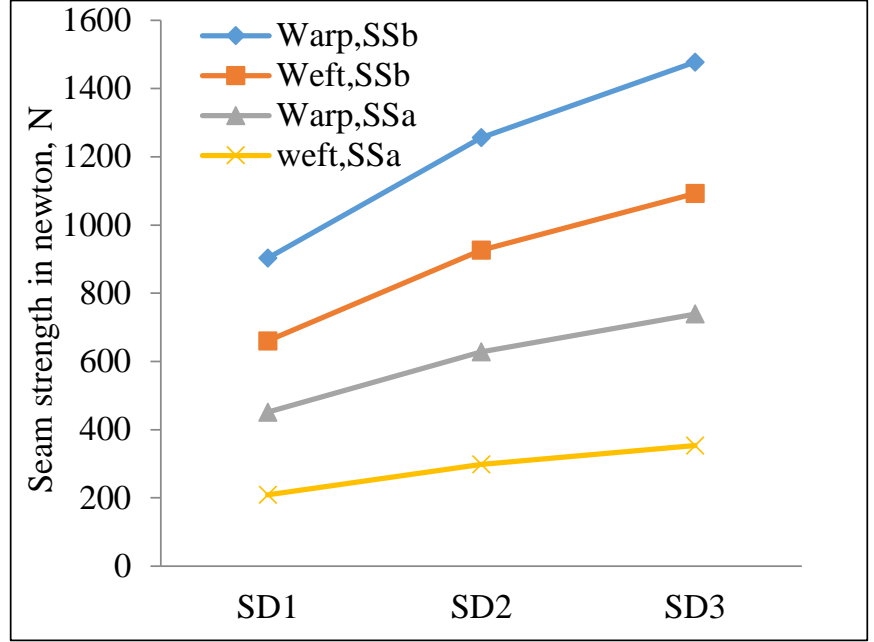

(b)

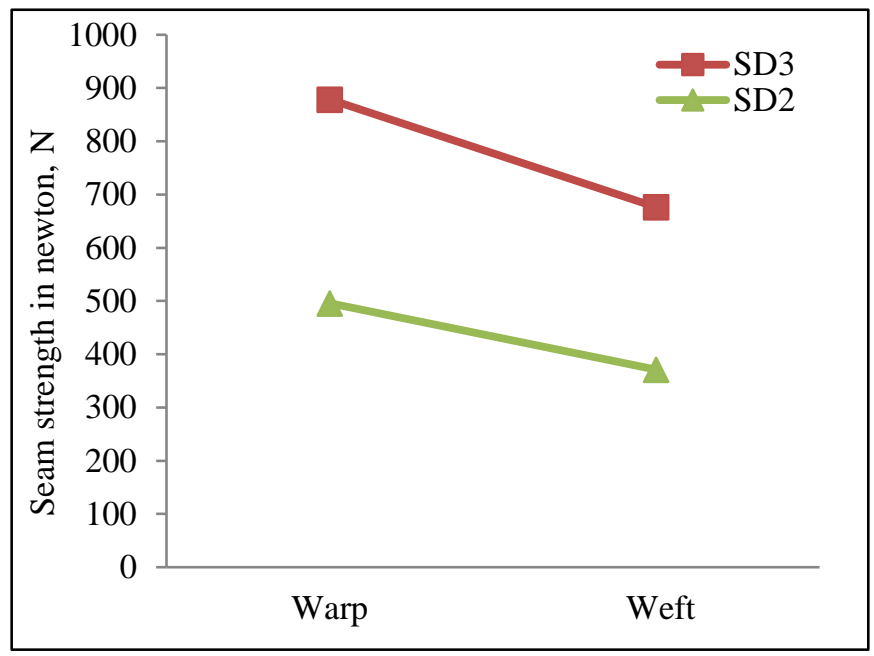

(d)

Fig. 4 Seam strength for various (a) seam type \& (b) stich density and (c) seam type \& (d) seam direction

3.5 Regression Analysis to Develop Regression Equation

The regression equation is given below:

Seam strength $=-568.318+312.742 \times$ Sewing Thread $+53.029 \times$ Stitch Density $+68.011 \times$ Seam type $67.996 \times$ Seam direction

Table 5 Regression model summary

\begin{tabular}{ccccc}
\hline $\mathbf{R}$ & $\mathbf{R}^{\mathbf{2}}$ & Adjusted R $^{\mathbf{2}}$ & Std. Error & Sig. \\
\hline $.913^{\mathrm{a}}$ & .833 & .812 & 131.9538486 & .000
\end{tabular}

a Predictors: (Constant), Seam direction, Seam type, Stitch Density,

Sewing Thread, Stitch Type

As in the Table 5, the $\mathrm{R}^{2}$ value is $83.3 \%$ which indicates the prediction level of the model. The $\mathrm{R}^{2}$ value also denotes that $83.3 \%$ of the changes in seam strength (dependent variables) can be explained by independent variables in the model. According to the results of ANOVA test presented in Table 6, it is found that the relation between dependent and independent variables was significant at $99 \%$ significance level as the significance value was found as $p<0.01$. The regression equation (equation 1) given above was made with the coefficients obtained by the analysis in this study. The regression equation will help to predict seam strength when the other independent variables are known before the production process.

Table 6 Regression analysis, ANOVA $^{\mathrm{a}}$

\begin{tabular}{cccccc}
\hline Model & Sum of Squares & df & Mean Square & F & Sig. \\
\hline Regression & 2700578.351 & 4 & 675144.59 & 38.78 & $0^{\mathrm{b}}$ \\
Residual & 539766.363 & 31 & 17411.82 & & \\
Total & 3240344.714 & 35 & & & \\
\hline
\end{tabular}

a. Dependent Variable: Seam strength

b. Predictors: (Constant), Seam direction, Seam type, Stitch Density, Sewing Thread

\section{CONCLUSION}

The outcome of the research shows that the studied sewing parameters affect the strength of lockstitch seam significantly. There is slight increase in seam strength as the layers of the fabric increased. Though seam strength is found higher with the coarser sewing threads and with the higher stitch densities, these two 
factors should be selected in such a way so that the seam quality remains satisfactory because some samples were found with slipped seam at eleven stitches per inch; this may denote the unsuitability of eleven stitches per inch for the fabric. The effect of seam direction was more visible for the sewing thread three, ST3 (60 Tex). Prediction of seam quality before seam production is the most important issue for the manufacturers. And for this reason, regression model has been developed that will allow the producers to predict seam strength from given input parameters. The outcome of the work can be more generalized by including kind of fabrics as an independent variable and by producing seams with other stitches that are commonly used for denim fabrics.

\section{REFERENCES}

[1] Frydrych, I. and Greszta, A., 2016. Analysis of lockstitch seam strength and its efficiency. International Journal of Clothing Science and Technology, 28(4), pp.480-491.

[2] Abdul Ghani, S., 2011. Seam performance: Analysis and Modelling (Doctoral dissertation, University of Manchester).

[3] Tyler, D.J. ed., 2009. Carr and Latham's technology of clothing manufacture. John Wiley \& Sons.

[4] B. K. Behera and S. Sharma, 1998. Low-stress behaviour and sewability of suiting and shirting fabrics, Indian Journal of Fibre and Textile Research, 23, pp. 233-241.

[5] Merkel, R.S., 1991. Textile product serviceability. Macmillan.

[6] Glock, R.E. and Kunz, G.I., 2005. Apparel manufacturing: Sewn product analysis (p. 345). Upper Saddle River, NJ: Pearson/Prentice Hall.

[7] Azam, M. S., Saleh, M. A., Nafiz, K., 2009, An introductory knowledge about garments manufacturing technology, Dhaka, Bangladesh: Books Fair Publications, Page No.155.

[8] Ukponmwan, J.O., Mukhopadhyay, A. and Chatterjee, K.N., 2000. Sewing threads. Textile progress, 30(3-4), pp.1-91.

[9] Bharani, M., Shiyamaladevi, P.S.S. and Mahendra Gowda, R.V., 2012. Characterization of seam strength and seam slippage on cotton fabric with woven structures and finish. Research journal of engineering sciences, 1(2), pp.41-50.
[10] Choudhary, A.K. and Goel, A., 2013. Effect of some fabric and sewing conditions on apparel seam characteristics. Journal of Textiles, 2013. pp. 1-7.

[11] Barbulov-Popov, D., Cirkovic, N. and Stepanović, J., 2012. The influence of stitch density and of the type of sewing thread on seam strength. Tem Journal, 1(2), pp.104-110.

[12] Solinger, J., 1980, Apparel Manufacturing Handbook, Newyork, USA: Van Nostrand Reinhold Company, pp. 168.

[13] Rengasamy, R.S., Kothari, V.K., Alagirusamy, R. and Modi, S., 2003. Studies on air-jet textured sewing threads. Indian Journal of Fibre \& Textile Research, 28, pp. 281287

[14] Nayak, R., Padhye, R., Dhamija, S. and Kumar, V., 2013. Sewability of air-jet textured sewing threads in denim. Journal of Textile and Apparel Technology and Management (JTATM), 8(1), pp.1-11.

[15] Zervent Ünal, B., 2012. The prediction of seam strength of denim fabrics with mathematical equations. Journal of The Textile Institute, 103(7), pp.744-751.

[16] Sarhan, T.M.A., 2013. Interaction between sewing thread size and stitch density and its effects on the seam quality of wool fabrics.Journal of Applied Sciences Research, 9(8), pp.4548-4557.

[17] Akter, M. and Khan, M.R., 2015. The effect of stitch types and sewing thread types on seam strength for cotton apparel. International Journal of Scientific \& Engineering Research, 6(7), pp.198-205.

[18] Yassen, H.A., 2017. Study of the Relationship between sewing and fabric Parameters and Seam Strength. International Design Journal, 7(2), pp.125-129.

[19] Rajput, B., Kakde, M., Gulhane, S., Mohite, S. and Raichurkar, P.P., 2018. Effect of sewing parameters on seam strength and seam efficiency. Trends in Textile Engineering and Fashion Technology, 4 (1), pp.4-5.

[20] Regar, M.L., Sinha, S.K. and Choubisa, B., 2018. EliTwist sewing thread-an alternative to conventional thread. Research Journal of Textile and Apparel, 22 (2), pp.126-137. 